\title{
Impact of Job Satisfaction and Commitment to Performance: Organizational Citizenship Behavior (OCB) as a Mediator (Research on Teachers in State Islamic Elementary Schools (MIN) in Banda Aceh)
}

\author{
Muhammad Idris Tumanggor ${ }^{1} \quad$ Nurdasila Darsono $^{2} \quad$ Mahdani Ibrahim $^{2 *}$ \\ 1.Master of Management at Faculty of Economics and Business Universitas Syiah Kuala, \\ Banda Aceh - Indonesia \\ 2.Lecturer at Faculty of Economics and Business Universitas Syiah Kuala \\ Banda Aceh - Indonesia
}

\begin{abstract}
This study aims to examine the hypothesis of the role of variable citizen organizational behavior (OCB) as an intervention variable in the relationship between job satisfaction and work commitment to teacher performance. This research was conducted on teachers in state Islamic elementary schools (MIN) in Banda Aceh. The study sample was 125 teachers taken based on probability sampling methods. To get the primary data, the researcher prepared a questionnaire which was circulated to a predetermined sample. Measurement of variables studied using a Likert scale with scores from strongly disagree $=1$ to strongly agree $=5$. Data were analyzed using the Structural Equation Modeling (SEM) method, by using AMOS as a data analysis tool. The results showed that posotive and significant OCB variables played a role as intervention variables in the relationship between job satisfaction and commitment of MIN teachers in Banda Aceh. Direct and indirect influences between variables in this study we present in the discussion section of the results of this study.
\end{abstract}

Keywords: Job satisfaction, Commitment, OCB, Peformance, Teacher

DOI: $10.7176 / \mathrm{JEP} / 10-6-07$

\section{Introduction}

The teacher is a very valuable asset for a nation and country because the teacher is at the forefront of guarding and maintaining national culture. Because of that the role of the teacher in growing the nation's shoots in lieu of generation to generation is very important. In carrying out their functions as teachers in state Islamic elementary schools (MIN), they have the emotions that can be felt in carrying out their duties, such as feeling satisfied or dissatisfied. These feelings are influenced by work environment and competency factors (Iskandar \& Juhana, 2014; Ibrahim, Amir, \& Novita, 2018).

In the educational process, teacher behavior plays a very important role for the development of student personality. Good behavior from a teacher is not only competent and skilled in providing material in front of the class, but it must be more than that because a teacher is a role model and partner for his students. The teacher must be careful about maintaining attitudes, behavior, appearance and speech wherever the teacher is. If the teacher ignores this, it will have negative implications for the development of the behavior of his students.Satisfaction received by teachers in schools is more important than the dissatisfaction experienced on each working day. Satisfaction felt by teachers should be very adequate at every time they work, this feeling is considered to positively influence teacher performance.

But if the teacher's experience of inadequate satisfaction is often experienced when performing their functions, it is considered to have an adverse effect on their performance. Achievement of teacher performance can be seen from 8 aspects of assessment criteria, namely: 1. curriculum content, 2. learning process, 3 . competency of graduates, 4. teaching staff, 5. facilities, 6. management of education, 7. financing of education, and 8 educational assessment (Iskandar \& Juhana, 2014; Yunus, Ibrahim \& Amir, 2018).

Furthermore, in addition to having a sense of satisfaction and dissatisfaction with the teacher, they also have the feeling of wanting to change the conditions of work conditions of their organization with an attitude of work commitment, in which they promise themselves to always survive while improving poor conditions for the better. If these actions are carried out by the teachers, it is expected to improve performance to the better.

But if this action is not carried out or ignored, the better performance expected is difficult to achieve. Law of the Republic of Indonesia Number 20 of 2003 concerning National Education System Chapter I Article 1 concerning General Provisions states that Education is a conscious and planned effort to create a learning atmosphere and learning process so that students actively develop their potential to have religious spiritual power, control self, personality, intelligence, noble character, and skills needed by him, society, nation and country. To achieve performance as mandated by law, the work commitment of the teachers is highly expected.

OCB is an organizational behavior that needs to be applied in various fields, one of which is the field of education carried out by teachers. Teacher OCB is divided into three, namely OCB that is done to students, 
teams or colleagues, and organizations, namely schools (Somech \& Drach-Zahavy, 2000). Teachers who display OCB are examples of good teachers. If the teacher has a high OCB, then indirectly they will be ready to do work outside the job description (Mira \& Desty, 2017). If in an organization it has people with high levels of OCB, it is hoped that the organization will be able to face challenges that arise from environmental changes, both internal and external (Humairo \& Mulyana, 2013; Mira \& Desti, 2017).

At present the teacher is still unable to position himself as an educator and learning partner. If seen in the education process, one of the important factors is making a professional teacher, namely by fostering caring, responsibility, and loving care for the teacher towards his students, so that more meaningful learning can be created.

For teachers, a good personality is a necessity that must be possessed, as well as a commitment that becomes a standard for every teacher in carrying out his duties and profession as an educator. Based on the background above, the authors are interested in knowing how job satisfaction factors and teacher commitment affect OCB and OCB mediate the relationship of job satisfaction and teacher commitment to improve teacher performance.

\section{Literature Review}

\subsection{Factors affecting of performance}

Performance is a word that has no universal definition (Anderse' $\mathrm{n}, 2010$ ). (Anonymous, 2012), performance is an action or process in carrying out an activity or function, which is seen in this case is how successful it is done. Performance measures are often associated with energy released by a person in an effort, while one's performance is measured by the results that have been done, this is often confusing (Shanthi et al., 2012).

According to Erdogan (1991), performance is defined as the realization of tasks assigned to employees based on their personal qualifications within reasonable limits. Whereas Ivancevich, Konopaske and Matteson (2005), performance is a function of capacity, opportunity and desire to do a task.

In addition, performance can also be said as the achievement of tasks assigned to employees and the results produced in certain functions or work activities within a given period of time. When we look at teacher performance, we consider work related to academics, academic staff, educators to mean someone who provides teaching or education that refers to lecturers, tutors and administrative staff in educational institutions (Anonymous, 2012).

From some of the opinions above, this study defines performance as the result of work both qualitatively and quantitatively by an educator in accordance with the demands of the work carried out. The performance of a teacher is expected to experience an increase from time to time.

Improving one's performance is influenced by many factors, some experts argue that there are several factors that affect performance, Mathis and Jackson (2011) and Armstrong (2012), they agree that factors that can affect performance related to organizational environments such as: management support, culture training, organizational climate, and the dynamics of the organization's environment, while those related to work are: communication, autonomy and the environment. Factors related to employees, such as intrinsic motivation, proactivity, adaptability, skill flexibility, commitment and skill level.

In addition, job satisfaction has a positive effect on improving performance (Judge, Bono, Thoresen, \& Patton, 200; Falkenburg \& Schyns, 2007; Siengthai \& Pila-Ngarm, 2016).

Work commitment influences employee performance improvement (Mathis \& Jacson, 2011; Armstrong, 2012; vanGelderen \& Bik, 2016). Unit level OCB is related to unit effectiveness (Ehrhart et al., 2006), and OCB has a significant effect on performance evaluation decisions (Allen, 1998, \& Whiting et al, 2008).

OCB affects performance in organizations (Basu, Tewari, \& Pradhan, 2017). Factors that influence the performance of educators are mostly categorized in the practice of Human Resources (Mohd, Mustapha \& Mahmud, 2009). A number of researchers have determined the relationship between HR practices and employee performance and the results of the study show a positive relationship between them (Cai \& Lin, 2006; Mohd, Mustapha \& Mahmud, 2009; Shahzad, Bashir \& Ramay, 2008; Vlachos, 2009).

\subsection{Factors affecting of organizational citizenship behavior (OCB)}

Organizational citizenship behavior (OCB) is an individual behavior that is free (discretionary) and does not directly and explicitly accept awards from the formal reward system, and overall effectiveness encourages organizational function (Wardhani \& Adji, 2017). In line with the opinion of Wardhani \& Adji, by Podsakoff et al. (2000) emphasize again that OCB run by an employee in the organization is without reward, because work is initiated voluntarily with good intentions from an employee, and this behavior is not a requirement of the organization, but good intentions of the employee to do so, and none in the context of their duties, this is only a form of empathy to help others in their work, which in turn will help achieve organizational goals.

Organizational citizenship behavior as an influential moderator variable between personality, organizational commitment and job satisfaction on performance (Wardhani \& Adji, 2017). Job satisfaction affects OCB and job 
satisfaction mediates between meaningful work and OCB (SunHee \& Lee, 2017). Previous research supports the fact that organizational commitment is a strong predictor of OCB (Meyer et al., 2002). Employee commitment can influence OCB (Pohl \& Paillé, 2011). Based on several opinions described above, then to complete the research plan, researchers have designed a research model as shown in Figure 1.

\subsection{Research framework}

This research framework refers to the results of the literature review. This study prepared 4 variables in observing the practice of HR in schools, namely 2 exogeneous variables which included work satisfaction variables which were characterized by X1 and teacher work commitment variables which were marked with X2. Furthermore, the OCB variable is a mediating variable, this variable can function as veriabel endogeneus and exogeneus, which is indicated by Y. Besides that, it is a predictable variable, namely the teacher performance variable which is an endogeneous variable which is marked with $\mathrm{Z}$.

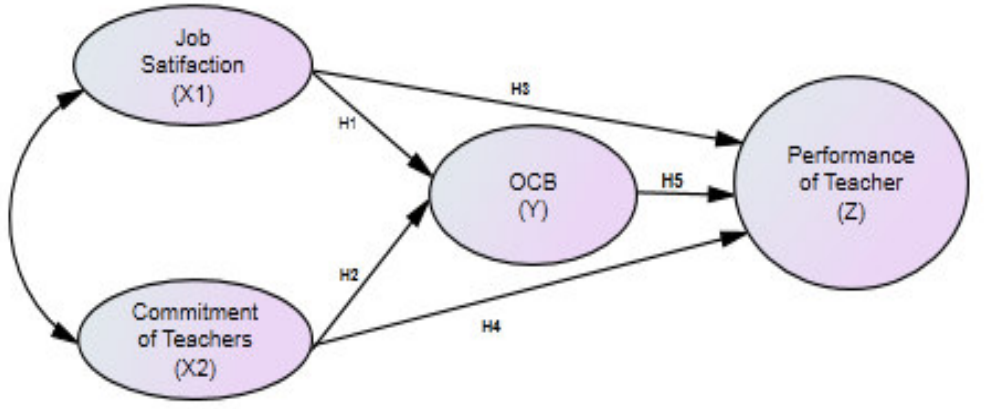

Figure 1. Research Framework

Based on the research framework, the research hypothesis can be formulated as follows:

\subsection{Hypothesis}

Ho1: Job satisfaction does not have a significant effect on OCB

Ha1: Job satisfaction has a significant effect on OCB

Ho2: Teacher commitment does not have a significant effect on OCB

$\mathrm{Ha}$ 2: Teacher commitment has a significant effect on OCB

Ho3: Job satisfaction does not have a significant effect on teacher performance

Ha3: Job satisfaction has a significant effect on teacher performance

Ho4: Teacher commitment does not have a significant effect on teacher performance

Ha4: Teacher commitment has a significant effect on teacher performance

Ho5: OCB satisfaction does not have a significant effect on teacher performance

Ha5: OCB satisfaction has a significant effect on teacher performance

Ho6: There is no mediation of OCB on the influence between job satisfaction and teacher performance

Ha6: OCB mediates influence between teacher satisfaction and teacher performance

Ho7: There is no mediation of OCB on the influence between teacher commitment and teacher performance

Ha7: OCB mediates the influence between teacher commitment and teacher performance

\section{Methodology}

The study was conducted at 4 state Islamic elementary schools in Banda Aceh with a population of 125 teachers. Because the population is relatively small, all respondents are used as respondents. So the method of selecting sample members uses census techniques. Primary data from respondents obtained by questionnaire method circulated to all respondents who have been determined.

Measurement of variables studied using several relevant indicators, measuring indicators using a Likert scale with the lowest score $=1$ to the highest $=5$. Data were analyzed using structural equation modeling (SEM) method with the help of analysis of a moment structures (AMOS) equipment. Instrument testing is done by testing validity and reliability.

\section{Results and Discussion}

\subsection{Effect of job satisfaction (X1) and work commitment (X2) on OCB (Y)}

Table 1 is the test results of Confirmatory factors analysis (CFA) on the influence between variables on the model studied. Job satisfaction variable (X1) shows a probability value of 0.007 , because the probability value is lower than 0.05 , then the variable (X1) has a significant effect on the OCB variable (Y). Furthermore, the work commitment variable (X2) where the probability of getting a critical ratio is 2,989 , at a significance level $=0.003$, because the probability value is below 0.05 , it can be said that the (X2) variable has a significant effect on OCB 
(Y) variables. Based on these results, the hypothesis (Ha1 and Ha2) is accepted.

Table 1. CFA Test results between variable effects

\begin{tabular}{lclcccc}
\hline & & & Estimate & S.E & C.R & P \\
\hline OCB (Y) & $\leftarrow$ & Job_Satisfaction (X1) & 0.377 & 0.140 & 2.689 & 0.007 \\
OCB (Y) & $\leftarrow$ & Commitment (X2) & 0.356 & 0.119 & 2.989 & 0.003 \\
Performance (Z) & $\leftarrow$ & Commitment (X2) & 0.232 & 0.086 & 2.694 & 0.007 \\
Performance (Z) & $\leftarrow$ & Job_Satisfaction (X1) & 0.333 & 0.103 & 3.225 & 0.001 \\
Performance (Z) & $\leftarrow$ & OCB (Y) & 0.181 & 0.068 & 2.666 & 0.008 \\
\hline
\end{tabular}

Source: Raw data processed 2018

\subsection{Effect of job satisfaction (X1) and work commitment (X2) on teacher performance (Z)}

Based on the results of the CFA test in Table 1 shows that job satisfaction (X1) has a significant effect on teacher performance $(Z)$ and teacher work commitment, it also has a significant effect on $(Z)$. This is evidenced by the results of the CFA where the value of the critical ratio (CR) is 2.225 at the significance level $\alpha=0.001$ for the variable (X1) predicting (Z), and (CR) of 2.694 with a significance level $\alpha=0.007$ for the teacher work commitment variable (X2) The two variables (X1) and (X2) are evidently proven to have a direct influence on teacher performance $(\mathrm{Z})$, because the probability value is $<0.05$. With these results, the hypothesis $(\mathrm{Ha} 3$ and $\mathrm{Ha} 4)$ is accepted.

\subsection{Effect of $\mathrm{OCB}(\mathrm{Y})$ on teacher performance $(\mathrm{Z})$}

The CFA test results in Table 1 show a C.R value of 2,666 with a significance level of $\alpha=0.008$ which indicates less than 0.005 , so it can be said that the variable organizational citizenship behavior (OCB) or (Y) can be said to have a significant effect on teacher performance $(Z)$. From these results it can be concluded that hypothesis (Ha5) is acceptable.

\subsection{The role of $\mathrm{OCB}(\mathrm{Y})$ as a mediator between job satisfaction (X1) and work commitment (X2) on teacher performance $(\mathrm{Z})$}

Mediation or intervening hypothesis testing is done by a procedure developed by Sobel (1982) and known as the Sobel test (Ghozali, 2011). The Sobel test is carried out by testing the strength of the indirect effect (X) to (Z). The indirect effect $(\mathrm{X})$ to $(\mathrm{Z})$ through $(\mathrm{Y})$ is calculated by means of path $\mathrm{X}-\mathrm{Y}=(\mathrm{a})$ with the path $\mathrm{Y}-\mathrm{Z}=(\mathrm{b})$ or $\mathrm{ab}$. So the coefficient $a b=(c-c !)$ Where $c$ ! is the effect of $X 1$ on $Z$ without controlling $Y$. Whereas $c$ ! is the coefficient of influence of $\mathrm{X}$ on $\mathrm{Z}$ after controlling $\mathrm{Z}$.

Table 2. CFA Test results the amount of influence based on standardized estimate

\begin{tabular}{lllcc}
\hline & & & S.E & Standardized Estimate \\
\hline OCB_Y & $<---$ & Job_satisfaction_X1 & 0.140 & 0.255 \\
OCB_Y & $<---$ & Work_commitment_X2 & 0.119 & 0.263 \\
Teacher_perf_Z & $<---$ & Work_commitment_X2 & 0.086 & 0.239 \\
Teacher_perf_Z & $<---$ & Job_satisfaction_X1 & 0.103 & 0.313 \\
Teacher_perf_Z & $<---$ & OCB_Y & 0.068 & 0.252 \\
\hline
\end{tabular}

Source: Raw data processed 2018

The Sobel-Test results, an Interactive calculation tool for mediation tests where the value of the test statistic obtained a value of 1,634 , is smaller than the minimum CR that is required which is equal to 1.96 or equal to $(1,634<1.96)$ standard error value of 0.064 . Based on the results of significant calculations for line $\mathrm{c}$ ! by using the Sobel test, the significant values for all paths (A, B, C and c!) can be seen in Figure 2.

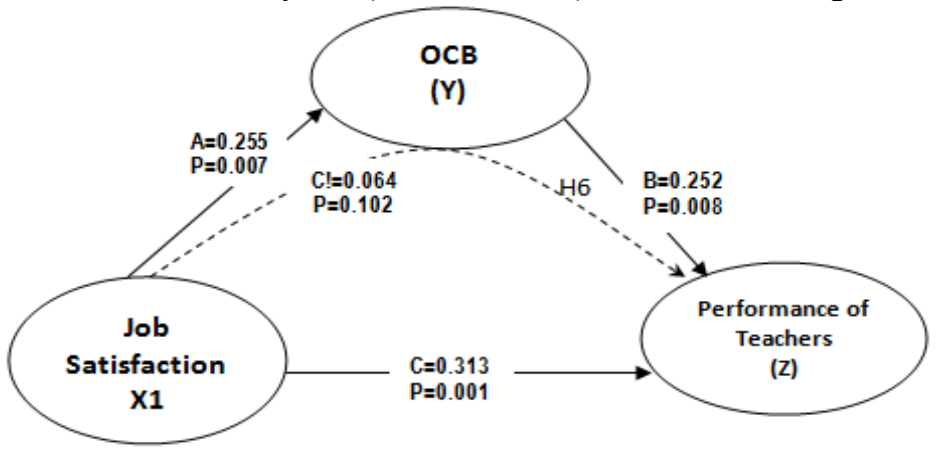

Figure 2. Test Results of the Role of Mediation OCB on The Influence of Job Satisfaction and Teacher Performance 
Figure 2 is the test result of the role of mediating variables through Sobel-test. The test results show that the direct effect of the variable job satisfaction on teacher performance is 0.313 , while the variable effect of job satisfaction on teacher performance through organizational citizenship behavior is 0.064 . This means that if you want to improve Teacher's performance in Islamic elementary schools (MIN) in Banda Aceh, the party that has the authority makes a decision to pay attention to increasing job satisfaction through its indicators and through increasing OCB.

In the context of teacher performance, OCB must be a concern to use because its influence makes the correlation coefficient smaller, this variable is categorized as full mediating. Therefore OCB plays an important role in mediating the influence of job satisfaction on teacher performance. For the results of this study, the hypothesis (Ha6) is accepted. The results of this study are consistent with the research conducted by Indarti et al. (2017), which shows that higher job satisfaction will result in higher performance, mediated by OCB. Wardhani \& Adji (2017) found that OCB influences job satisfaction on improving performance.

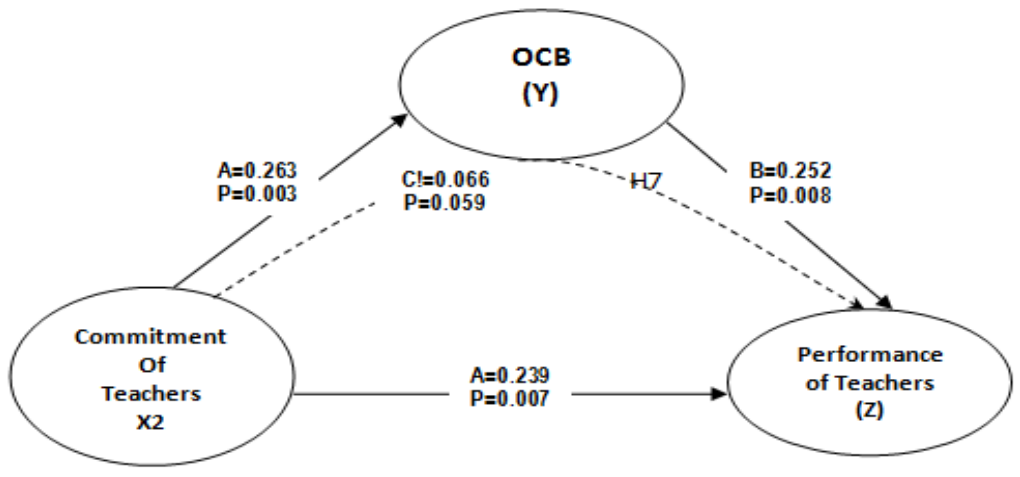

Figure 3. Role Test Results Mediation OCB on The Effect of Teacher Work Commitment on Teacher Performance

Figure 3 is the result of the role test of OCB as a mediator between teacher work commitments and teacher performance using the Sobel-test. The results of the examination show the direct effect of the variable work commitment on teacher performance is 0.239 . While the influence of work commitment variables on teacher performance through OCB is 0.066 . This means that if you want to improve the performance of teachers of state Islamic elementary schools (MIN) in Banda Aceh, it will be better for decision makers to continue to motivate teachers so that work commitments can increase.

The results of the study also showed that there was a role for OCB in the influence between work commitment and teacher performance at (MIN) in Banda Aceh City. The OCB variable mediates the influence between work commitment and teacher performance is fully mediation, because the coefficient value in the direct relationship is getting smaller with the intervention variable (Y). Based on the results of this study, the hypothesis (Ha7) is accepted. The results of this study are consistent with all the studies conducted by (Indarti et al. 2017; Wardhani \& Adji, 2017) \& Cahyaningdyah, 2013).

\section{Conclusions and Implications}

1. Job satisfaction for teachers in schools (MIN) in Banda Aceh City had a significant effect on OCB. This means that when feelings of satisfaction experienced by teachers increase, there will be an increase in behavior of OCB in schools (MIN) in Bnada Aceh. These findings are consistent with the findings (SunHee \& Lee, 2017). From the results of the study, the Ha1 hypothesis is accepted.

2. The work commitment of the teachers has a significant effect on $\mathrm{OCB}$, this means that when teachers have a high commitment to their work, OCB behavior among teachers at the School (MIN) can increase in Banda Aceh City. The results of this study provide answers to the hypothesis (Ha2). The results of the study also support findings from the results of previous studies (Meyer et al., 2002; and Pohl \& Paillé, 2011).

3. The results showed that job satisfaction of teachers in schools (MIN) in Banda Aceh had a significant effect on their performance. This means that when satisfaction increases among teachers, it will experience improvements both qualitatively and quantitatively towards their performance at the school. Based on the results of the research, the hypothesis (Ha3) is accepted. The results of the study are consistent with findings from previous studies (Judge, Bono, Thoresen, \& Patton, 200; Falkenburg \& Schyns, 2007; Siengthai \& Pila-Ngarm, 2016).

4. The performance of teachers is significantly influenced by work commitment, which means that teacher performance can be predicted by work commitment. In other words, when the teachers' commitment is getting better, it will have a positive impact on the performance of teachers at schools (MIN) in Banda 
Aceh. The results of this study accept the hypothesis statement (Ha4). Consistent with prior research (Mathis \& Jacson, 2011; Armstrong, 2012; vanGelderen \& Bik, 2016).

5. The results of the study found that the OCB variable had a significant effect on performance, which means that every teacher in the school (MIN) with OCB behavior gets higher, the performance of the teachers also increases higher. From these findings, the hypothesis (Ha5) is accepted. Several previous studies were consistent with the results of this study (Allen, 1998; Whiting et al., 2008; and Basu, Tewari, \& Pradhan, 2017).

6. In addition, the results of the study also found that the OCB variable had a strong role in mediating the influence between job satisfaction and work commitment on teacher performance. This means that the higher the behavior of OCB among teachers, due to feelings of satisfaction and high work commitment, OCB contributes to improving performance among teachers. The results showed that the hypothesis (Ha6 and Ha7) was accepted.

7. The results of this study can add to the contribution of ideas to leaders in educational institutions, where job satisfaction factors, commitment to work both among educators and non-educators can be a strategy to improve the performance of workers. The behavior of the citizenship of the organization carried out by teachers should be appreciated and this arises due to the factor of satisfaction, with this motivation they will be committed to their work which in turn will have a positive impact on the progress of the organization.

\section{References}

Allen, T. D. (1998), The Effects of Organizational Citizenship Behavior on Performance Judgments: A Field Study and a Laboratory Experiment.Journal of Applied Psychology, 83 (2), 247-260

Anderse'n, J. A. (2010). Critical examination of the EO-performance relationship. International Journal of Entrepreneurial Behaviour \& Research, 16(4), 309-328.

Anonymous. (2012), Oxford Dictionaries Online. http://oxforddictionaries.com /view/entry/m en gb0619520 \#m_en_gb 0619520. Accessed December 15, 2018.

Armstrong, M. (2012), A Handbook of Human Resource Management Practice, Kogan Page, London.

Basu, E., Tewari, H. R. \& Pradhan, R. K. (2017). Impact of Organizational Citizenship Behavior on Job Performance in Indian Healthcare Industries: The Mediating Role of Social Capital. International Journal of Productivity and Performance Management, 66 (6)

Cahyaningdyah, D. (2013). Pengaruh kecerdasan emosional, komitmen organisasional dan organizational citizenship behavior terhadap kinerja karyawan. Jurnal Dinamika Manajemen. http://journal.unnes.ac.id/nju/index.php/jdm ANALISIS, 4(2), pp.184-191.

Cai Y.H. \& Lin C.D. (2006), Frontiers of Education in China. SpringerLink, 1(1).

Ehrhart, M.G., Bliese, P.D. and Thomas, L.J. (2006). Unit-level OCB and unit effectiveness: examining the incremental effect of helping behavior. Human Performance, 19(2), 159-173.

Erdoğan, İ.(1991), İşletmelerde Personel Seçimi ve Başarı Değerleme Teknikleri, İstanbul, İstanbul İşletme Fakültesi.

Falkenburg, K. and Schyns, B. (2007), Work satisfaction, organizational commitment and withdrawal behaviors. Management Research News, 30(10), 708-723.

Humairo, H.D., \& Mulyana, O.P. (2013). Perbedaan organizational citizenship behavior (ocb) pada guru sekolah menengah kejuruan (smk) ditinjau dari status sekolah. Character, 2(2), 1-7.

Ibrahim, Mahdani., Amir, Fakhrurrazi., \& Novita, Ade,Celia. (2018), The Role Of Mediating And Moderating Factors On The Influence Of Behavioral Incivility On Counterproductive Work Behavior. International Journal of Business Management and Economic Review, 1 (05), 142-152.

Indarti, S. Solimun., Fernandes, A. A. R., Hakim, W. (2017), The effect of OCB in relationship between personality, organizational commitment and job satisfaction on performance. Journal of Management Development, 36(10), 1283-1293.

Iskandar, Sentot \& Juhana, Enceng. (2014), Pengaruh Kompetensi Dan Lingkungan Kerja Terhadap Kepuasan Kerja Serta Implikasinya Pada Kinerja Guru Di Sdn Baros Mandiri 5 Kota Cimahi. (The Influence of Competence and Work Environment on Job Satisfaction and Its Implications on Teacher Performance in Baros Mandiri 5 in Cimahi City). Jurnal Ekonomi, Bisnis \& Entrepreneurship, 8 (2), 86-98.

Ivancevich, J. M., Konopaske, R., Matteson, M. T.(2005), Organizational Behavior and Management, New York, McGraw-Hill/Irwin, 7th Edition.

Judge, T.A., Bono, J.C., Thoresen, C.J. and Patton, G.K. (2001), The job satisfaction-job performance relationship: a qualitative and quantitative review. Psychological Bulletin, 127(3), 376-407.

Mathis, R.L. and Jackson, J.H. (2011), Human Resource Management, South Western Cengage Learning, Mason, $\mathrm{OH}$.

Meyer, J. P., Stanley, D. J., Herscovitch, L. L., \& Topolnytsky, L.(2002), Affective, Continuance and Normative 
Commitment to the Organization: A Meta-Analysis of Antecedents, Correlates and Consequences. Journal Of Vocational Behavior, 61, 20-52.

Mira, Ariyani \& Desty Zulkarnain (2017), Organizational Citizenship Behavior (OCB) Pada Guru Ditinjau Dari Faktor Demografi. Jurnal Penelitian dan Pengukuran Psikologi, 6 (2), 73-81.

Mohd. Ishak. N., Mustapha. R. \& Mahmud. Z. (2009), UKM Leads Research on Emotional Intelligence. http://pkukmweb.ukm.my/ news/index.php/en/ typography /215-ukm-leads-research-onemotionalintelligence.html. Accessed on December 15, 2018

Pohl, S., Paillé, P. (2011), The impact of perceived organizational commitment and leader commitment on organizational citizenship behavior. International Journal of Organization Theory \& Behavior, 14(2), 145161. https:// doi. org/10.1108/IJOTB-14-02-2011-B001

Shahzad, K., Bashir, S., \& Ramay, M. I. (2008), Impact of HR Practices on Perceived Performance of University Teachers in Pakistan. Review of Business, 4(2), 302-315.

Shanthi, N., Vimala, K., Ramesh, K, Nurul N., Ahmad, K., \& Yusliza, M. Y. (2012), The Relationship of HR Practices and Job Performance of Academicians towards Career Development in Malaysian Private Higher Institutions. International Conference on Asia Pacific Business Innovation and Technology Management. Procedia - Social and Behavioral Sciences 57, 102 -118

Siengthai, S \& Pila-Ngarm, P. (2016), The interaction effect of job redesign and job satisfaction on employee performance. Evidence-based HRM: a Global Forum for Empirical Scholarship, 4(2),162180, https://doi.org/10.1108/EBHRM-01-2015-0001

Somech, A., \& Drach-Zahavy, A. (2000), Understanding extra-role behavior in schools: the relationships between job satisfaction, sense of efficacy, and teachers' extra-role behavior. Teachingand Teacher Education, 16, 649-659.

SunHee, J, \& Lee, Y. (2017), Understanding organizational citizenship behavior: the counselor's role. International Journal of Workplace Health Management, 10(6), 491-507.https://doi.org/10.1108/IJWHM05-2017-0030

Van Gelderen, B. R, \& Bik, L. W. (2016), Affective organizational commitment, work engagement and service performance among police officers", Policing. An International Journal of Police Strategies \& Management, 39(1), 206-221. https://doi.org/10.1108/ PIJPSM-10-2015-0123

Vlachos, I. P. (2009), High-performance workplace practices for Greek companies. EuroMed Journal of Business, 4(1), 21-39.

Wardhani, H, \& Adji, F. (2017), Moderation effect of organizational citizenship behavior on the performance of lecturers. Journal of Organizational Change Management,30(7),

Whiting, S.W., Podsakoff, P.M. and Pierce, J.R. (2008), Effects of task performance, helping voice, and organizational loyalty on performance appraisal ratings. Journal of Applied Psychology, 93(1),125-139.

Yunus, M., Ibrahim, M.,\& Amir, F. (2018), The Role of Customer Satisfaction and Trust as Mediation on The Influence of Service Quality and Corporate Image to Customer Loyalty. European Journal of Business and Management, 10(15), 121-128. 